\title{
DNA Nucleotidylexotransferase
}

National Cancer Institute

\section{Source}

National Cancer Institute. DNA Nucleotidylexotransferase. NCI Thesaurus. Code C16509.

DNA nucleotidylexotransferase (509 aa, $\sim 59 \mathrm{kDa}$ ) is encoded by the human DNTT gene.

This protein plays a role in DNA polymerization and specifically catalyzes the insertion of nucleotides ( $\mathrm{N}$ regions) at the $\mathrm{V}(\mathrm{H})-\mathrm{D}$ and $\mathrm{D}-\mathrm{J}(\mathrm{H})$ junctions of immunoglobulin genes. 